Reprod. Nutr. Dévelop., 1984, 24 (4), 419-429.

\title{
Studies on acrosome labelling of mammalian spermatozoa by radioactive sugars
}

\author{
V. KOPEĆNÝ, Dana ČECHOVÁ $(*)$, Blanka ŽELEZNÁ $\left({ }^{*}\right)$, J.-E. FLÉCHON $(* * *)$, \\ J. MOTLIK $\left(^{* *}\right)$, V. PECH $(* *)$
}

Research Institute of animal Production, CS 94992 Nitra and Institute of Histology and Embryology, J. E. Purkyně University, Brno.

(*) Institute of Molecular Genetics, Czechoslovak Academy of Science, Praha.

(**) Institute of Physiology and Genetics of Animals, Czechoslovak Academy of Science, Liběchov, Czechoslovakia.

(***) Station centrale de Physiologie animale, I.N.R.A., 78350 Jouy-en-Josas, France.

Summary. The localization of glycoprotein synthesis and storage was studied during acrosome formation in guinea-pig using fine-structure autoradiography after $\left({ }^{3} \mathrm{H}\right)$-fucose incorporation. Three days after $\left({ }^{3} \mathrm{H}\right)$-fucose injection, labelling in spermatids was concentrated in the matrix of developing acrosomes, and it was evident that the fucosylation of acrosomal glycoproteins largely overshadowed the fucosylation of other spermatid glycoproteins.

Acrosin labelling and its quantitative relation to labelling of other glycoproteins was examined in mature rabbit spermatozoa after incorporation of $\left({ }^{14} \mathrm{C}\right)$-fucose or $\left({ }^{14} \mathrm{C}\right)$ glucosamine during spermatogenesis. Cauda epididymis spermatozoa recovered 21 days after intratesticular application of $\left({ }^{14} \mathrm{C}\right)$-fucose or $\left({ }^{14} \mathrm{C}\right)$-glucosamine were analysed for acrosin specific labelling after acid extraction and gel filtration. In all the material examined, radioactivity was detected in the proacrosine fractions ; radioactivity in purified proacrosin amounted to at least $2 \%$ of the total radioactivity in the epididymal sperm population. In addition to the peak with radioactive proacrosin, another radioactive peak in $\left({ }^{14} \mathrm{C}\right)$ giucosamine-labelled material was attributed to a glycoprotein intraacrosomal inhibitor of acrosin.

It is concluded that (pro)acrosin (acrosin-inhibitor) complexes seem to contribute significantly to acrosomal glycoprotein labelling by radioactive sugars and that the distribution of these complexes may at least partly correspond to their cytochemically detectable component, acrosin. The superposition of the distribution of acrosin and of other acrosomal glycoproteins during acrosome reaction can be explained by the fact that the dispersal of most of the acrosomal content is linked to proacrosin activation.

\section{Introduction.}

Sperm acrosomal contents can be labelled by radioactive sugars (Kopečný and Fléchon, 1981). Because of the chemical specificity of the precursors used, particularly fucose, it was thought that different acrosomal glycoproteins were labelled in the spermatid during acrosome formation and that most of them 
" survived" in the acrosomal material until sperm maturity. In fact, Grootegoed et al., (1982) showed the fucosylation of several glycoproteins in rat spermatids. Consequently, our previous study (Kopečný and Fléchon, 1981) is only of statistical significance, revealing the general behavior of all fucose or glucosamine-containing glycoproteins. However, it is surprising that the subcellular distribution of acrosomal proteases or of the trypsin-like serine proteinase, acrosin (Gaddum and Blandau, 1970; Sakai and Yasuda, 1981; Green and Hockaday, 1978 ; Harrison et al., 1982 ; Huneau et al., 1983), before, and especially during, acrosome reaction, is very similar to our findings for all labelled acrosomal glycoproteins (Kopečný et al., 1980 ; Kopečný and Fléchon, 1981). The overlapping results include the localization of both radioactive proteins and enzymatic activities in the acrosomal matrix, their dispersal during acrosome reaction and the formation of diffusion " halos " around the sperm head, heavy labelling on the fenestrated acrosomal cap versus minimal or negative labelling on the denuded sperm head. As acrosin is a glycoprotein (for references see Anderson et al., 1981), it may be assumed from these observations that acrosin reflects the behavior of all or most of the other glycosylated acrosomal proteins.

The aim of the present work was to study the distribution of spermatid glycoproteins fucosylated already at the beginning of acrosome formation and to test the hypothesis of acrosin glycosylation at that time as well as to evaluate approximately the amount of acrosin in the glycosylated proteins of the mature acrosome. For the fine structure autoradiographic study, guinea-pig was chosen for the exceptional size of the acrosome of its spermatozoa, in order to increase the labelling resolution. For biochemical studies, rabbit was used as acrosin has already been amply analysed in this species (Meizel and Mukerji, 1979). A preliminary account of our results was presented at the Histochemical Symposium at Nedvedice, Czechoslovakia (1983).

\section{Material and methods.}

\section{1. - Autoradiography of guinea-pig testicular tissue.}

A mature male guinea-pig was injected intratesticularly with $\mathrm{L}\left(6-{ }^{3} \mathrm{H}\right)$-fucose (specific activity: $740 \mathrm{GBq} / \mathrm{mmol}$; CEA, Service des Molécules marquées, Saclay, France) per testis; the testes were recovered three days later and prepared for EM autoradiography using, as an additive to glutaraldehyde fixative, $0.5 \%$ (W/V) of cetyltrimethylammonium bromide for improved glycoprotein preservation (Kopečný and Fléchon, 1981). Thin sections showing gold interference colour were coated with Ilford L.4 nuclear liquid emulsion and exposed for one month. After staining, they were observed in either a Tesla 500 or Jeol JEM CXII electron microscope. The method of relative grain concentration, used for autoradiogram analysis, indicated the level of labelling in different spermatid cell compartments. 


\section{2. - Specificity of acrosin labelling.}

a) Sperm labelling and collection in rabbit. Eleven mature buck rabbits were injected intratesticularly with either $\mathrm{L}-\left(1-{ }^{14} \mathrm{C}\right)$ fucose (Amersham; specific activity : $2.19 \mathrm{GBq} / \mathrm{nmol}$ at a dose of about $1 \mathrm{MBq}$ per testis) or D-(L- $\left.{ }^{14} \mathrm{C}\right)$ glucosamine (Institute for Production, Research and Utilization of Radiotopes, Prague ; specific activity : $7.75 \mathrm{GBq} / \mathrm{nmol}$ at a dose of about $4 \mathrm{MBq}$ per testis) in a volume of $0.5 \mathrm{ml}$ of saline. Twenty-one days later, the caudae epididymides were isolated and the spermatozoa released through an incision in the epididymal tissue. As epididymal transit in rabbit is around 9 days $( \pm 1.5)$ according to Amann, Koefoed-Johnsen and Levi (1965), the duration of the testicular phase of sperm cell development from the stage of incorporation in acrosomal glycoproteins (round spermatids) was about 12 days $( \pm 1.5)$.

b) Acid extraction of epididymal spermatozoa. The extraction method using $0.25 \mathrm{M} \mathrm{H}_{2} \mathrm{SO}_{4}$ at $0{ }^{\circ} \mathrm{C}$ according to Meizel and Mukerji (1975) was applied with a modification: the luminal contents were extracted immediately after isolation. Acrosome destruction was monitored by electron microscopy. Dialyzed extracts were applied on Sephadex G-100 columns equilibrated and eluted with $0.001 \mathrm{M}$ $\mathrm{HCl}$. We collected $3.3 \mathrm{ml}$ fractions each in $15 \mathrm{~min}$ per $2.7 \times 95 \mathrm{~cm}$ column $\left({ }^{14} \mathrm{C}\right.$ fucose) and $1.2 \mathrm{ml}$ fractions each in $30 \mathrm{~min}$ per $1 \times 48$ column $\left({ }^{14} \mathrm{C}\right.$-glucosamine). Proacrosin content and radioactivity were assayed in the fractions, and those having proacrosin activity were pooled. The pooled fractions of $\left({ }^{14} \mathrm{C}\right)$-glucosamine-labelled material were further purified by hydrophobic chromatography on a Spheron P-300 $1 \times 4.8 \mathrm{~cm}$ column equilibrated with $0.3 \mathrm{M}$ acetic acid, $0.05 \mathrm{M} \mathrm{NaCl}, \mathrm{pH} 3.0$ (Železná and Čechová, 1982). After dialysis against the equilibration buffer in a volume of $6.8 \mathrm{ml}$, the sample was applied on the column, washed with the same buffer, and acrosin was eluted with a linear gradient of 1 $50 \%$ tertiarybutanol in the buffer $(40 \mathrm{ml}$ total $)$.

c) Acrosin, proacrosin and acrosin inhibitor assays. As described elsewhere (Železná and Čechová, 1982), acrosin activity and acrosin inhibitor activity were determined spectrophotometrically using $\mathrm{N}$-alfa-benzoyl-D, L-arginine-p-nitroanilide (BAPNA) as a substrate with the modification that the substrate was dissolved in di-methyl-formamide $(1 \mathrm{mg} / 0.1 \mathrm{ml})$. Proacrosin was assayed as acrosin after 2 hours of autoactivation (Mukerji and Meizel, 1979). One $\mathrm{mU}$ of enzyme (acrosin) activity hydrolyzed one nanomole of BAPNA per min. One proacrosin unit was equal to one acrosin unit after autoactivation. One mlU of inhibitor activity reduced the acrosin activity of one $\mathrm{mU}$.

d) Measurement of radioactivity. An aliquot $(0.5 \mathrm{ml})$ of each fraction was mixed with $7 \mathrm{ml}$ of Bray's solution (Spolana, Czechoslovakia) and checked for radioactivity by scintillation counting (Isocap II, Nuclear, Chicago).

e) Electrophoretic methods. Disc electrophoresis, protein staining and active enzyme staining were performed as described elsewhere (Železná and Čechová, 1982). Glycoproteins were assayed by a standard method using Schiff's reagent. 


\section{Results.}

1. - Fine-structure autoradiography of testicular tissue.

In guinea-pig seminiferous epithelium at 3 days postinjection, label was found in Golgi apparatuses of spermatocytes and spermatids ; the prevailing part of the label was connected with the forming acrosome (fig. 1) : heavy labelling was seen in proacrosomal granules, the acrosomal granule and the acrosomal vesicle. Some labelling could also be attributed to postacrosomal vesicles (Courtens, 1979), (fig. 2) and/or to material around the newly formed manchette. The label persisted in the acrosomal matrix in succeeding steps of acrosome development (figs. 3, 4) up to late spermatid stages with condensed nuclear chromatin. The analysis of relative grain concentration in the autoradiograms revealed that the label concentration in the spermatid acrosomal matrix was two orders of magnitude higher than that in other spermatid cell compartments.

\section{2. - Purification and quantification of radioactively labelled acrosin.}

The acid extracts applied on the columns contained approximately $20 \%$ of the total radioactivity present in the luminal contents of the rabbit caudae epididymides. About $30 \%$ of the radioactivity remained in the pellet after centrifugation, although the acrosomes had been entirely destroyed by the extraction procedure, as verified by electron microscopy. Quantitative data on further labelled acrosin purification are given on tables 1 and 2 .

\section{TABLE 1}

Specific activities and purification factors after particular isolation steps of both ${ }^{14} \mathrm{C}$-glacosamine and ${ }^{14} \mathrm{C}$-fucose-labelled proacrosins.

\begin{tabular}{ccccc}
\hline & \multicolumn{2}{c}{$\begin{array}{c}{ }^{14} \text { C-Glucosamine- } \\
\text { labelled proacrosin }\end{array}$} & \multicolumn{1}{c}{$\begin{array}{c}{ }^{14} \text { C-Fucose- } \\
\text { labelled proacrosin }\end{array}$} \\
\hline Isolation step & Acid extract & Sephadex & G-100 & G-Spheron P-300 Sephadex G-100 \\
\hline Specific activity $\mathrm{mU} / \mathrm{mg} \ldots$ & 2.6 & 90.0 & 400.0 & 280.0 \\
\hline Purification factor $\ldots \ldots \ldots$ & 1 & 35 & 154 & 108 \\
\hline
\end{tabular}

\section{TABLE 2}

Amount of radioactivity obtained after chromatography of fractions with proacrosin activity.

\begin{tabular}{cccccc}
\hline $\begin{array}{c}\text { Purification } \\
\text { of proacrosin } \\
\text { labelled by }\end{array}$ & Column bed & $\begin{array}{c}\text { Acid extract } \\
\text { applied on the } \\
\text { column }\end{array}$ & $\begin{array}{c}\text { Pooled proacrosin-rich fractions } \\
\text { after column } \\
\text { chromatography }\end{array}$ \\
\cline { 3 - 6 } & & cpm & cpm & $\%$ & $\left(\%{ }^{*}\right)$ \\
\hline${ }^{14} \mathrm{C}$-glucosamine & $\begin{array}{c}\text { Sephadex G-100 } \\
\text { Spheron P-300 }\end{array}$ & $\begin{array}{l}8000 \\
1600\end{array}$ & 4460 & 43 & $(8.6)$ \\
\hline & & & 400 & 25 & $(2.1)$ \\
\hline${ }^{14} \mathrm{C}$-fucose & Sephadex G-100 & 3300 & 1220 & 37 & $(7.4)$ \\
\hline
\end{tabular}

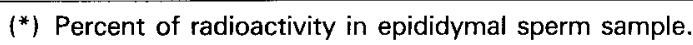



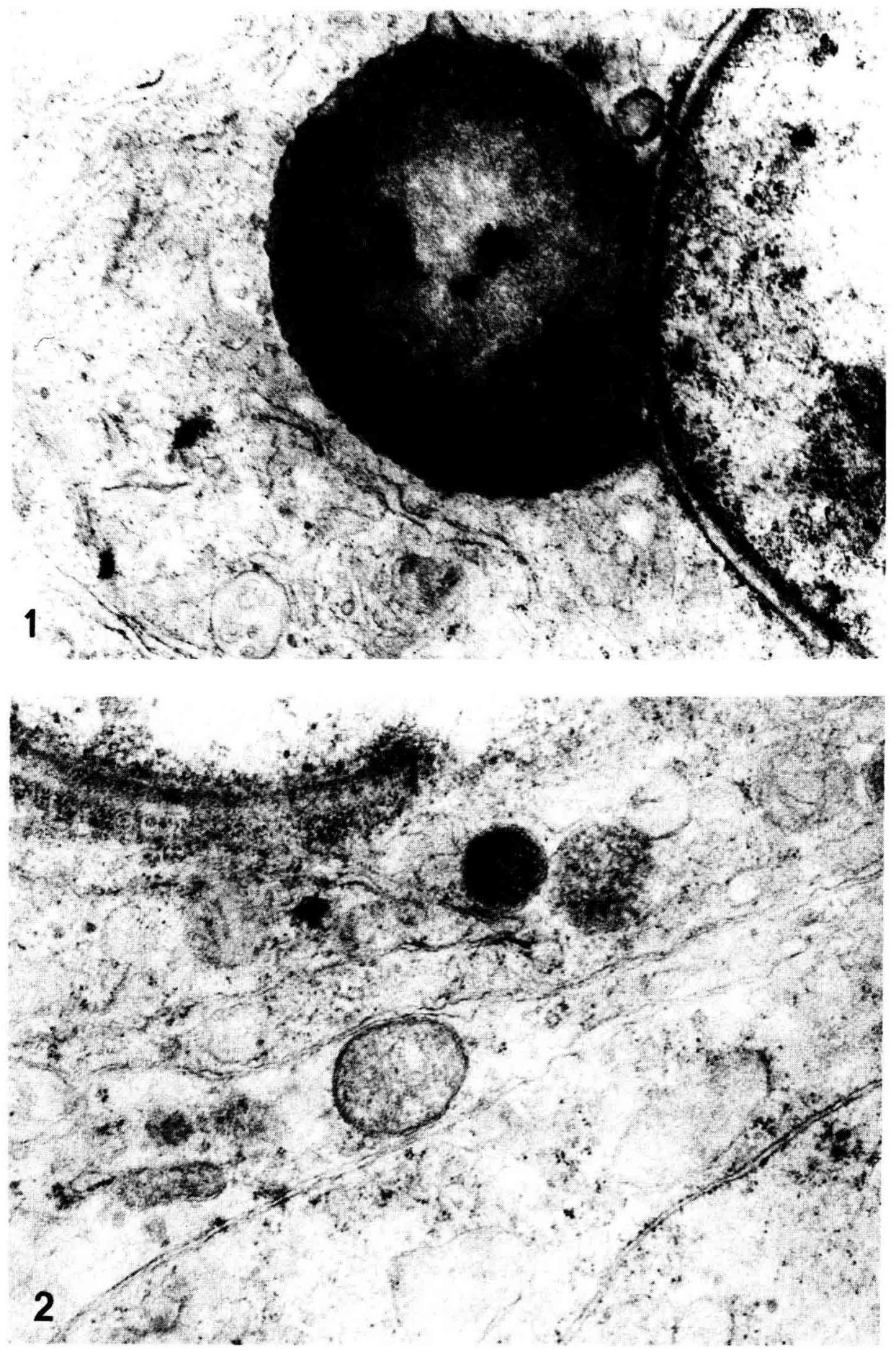

PLATE I. - Fine structure autoradiograms of guinea-pig spermatids three days after an intratesticular injection of $\mathrm{i}^{3} \mathrm{H}$ )-fucose. Patterns of labelling observed in the acrosomal granule (FIG. 1 $\times 17000$ ) and a postacrosomal granule (FIG. $2-\times 25000$ ) of round spermatids. 

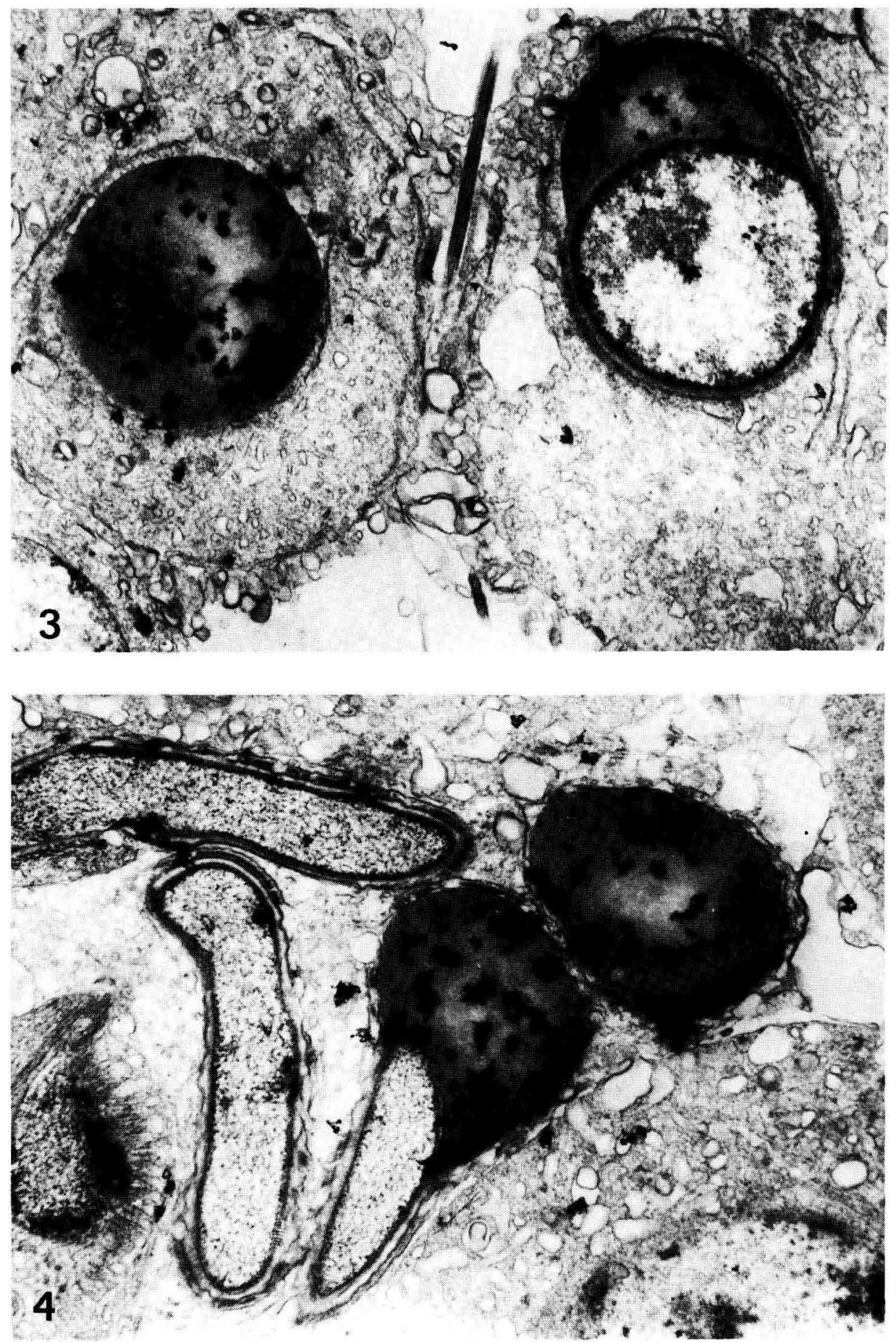

PLATE II. - Same material as for Plate /. Label accurnulated in the matrix of the developing acrosome of round (FIG. $3-\times 7000$ ) and elongating spermatids (FIG. $4-\times 9000$ ). 
The gel filtration elution profile of the acid extract from ${ }^{14} \mathrm{C}$-fucose-labelled spermatozoa (fig. 5) shows clearly that the radioactivity peak was superimposed to the acrosin activity peak (after autoactivation); the absorbance peak was positioned just next to it, except for a small amount of radioactive material in the void volume of the column. The lyophilized material, obtained by pooling fractions with acrosin activity, showed a high acrosin activity (after autoactivation) compared to other attempts to isolate rabbit proacrosin (Meizel and Mukerji, 1975 ; Mukerji and Meizel, 1979).

To obtain highly purified radioactive proacrosin we used $\left({ }^{14} \mathrm{C}\right)$-glucosamine labelling. In this second experiment, we applied column affinity chromatography after gel filtration. Spheron P-300 was chosen as a support since it was possible to use chromatography at $\mathrm{pH} 3.0$, thus avoiding proacrosin autoactivation. It is seen from the elution profile that two asymmetric peaks of (A280) absorbancy and radioactivity were eluted. The peak of proacrosin activity was exactly superimposed to the second absorbancy and radioactivity peaks (fig. 6).

We obtained the highest degree of proacrosin purification $(400 \mathrm{mU} / \mathrm{mg})$ from the hydrophobic step of the chromatography (fig. 6). Proacrosin homogeneity was determined by disc electrophoresis. A single protein band showing acrosin activity after activation was also stained with Schiff's reagent. The first peak of high radioactivity (fig. 6) corresponded to strong acrosin inhibitor activity.

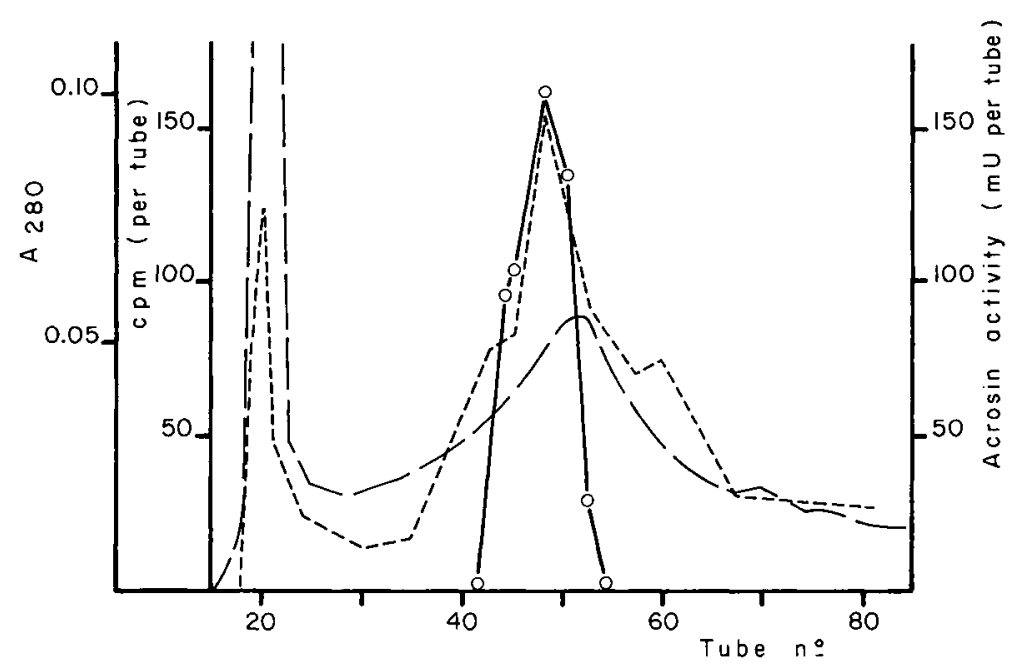

FIG. 5. - Gel filtration of acidic extracts of ${ }^{14} \mathrm{C}$-fucose labelled spermatozoa. - - Absorbance at $280 \mathrm{~nm}$; -..- Radioactivity (minus background); $\mathrm{O}---\mathrm{O}$ Acrosin activity after $1 \mathrm{hr}$ activation. Conditions : see Material and Methods. 


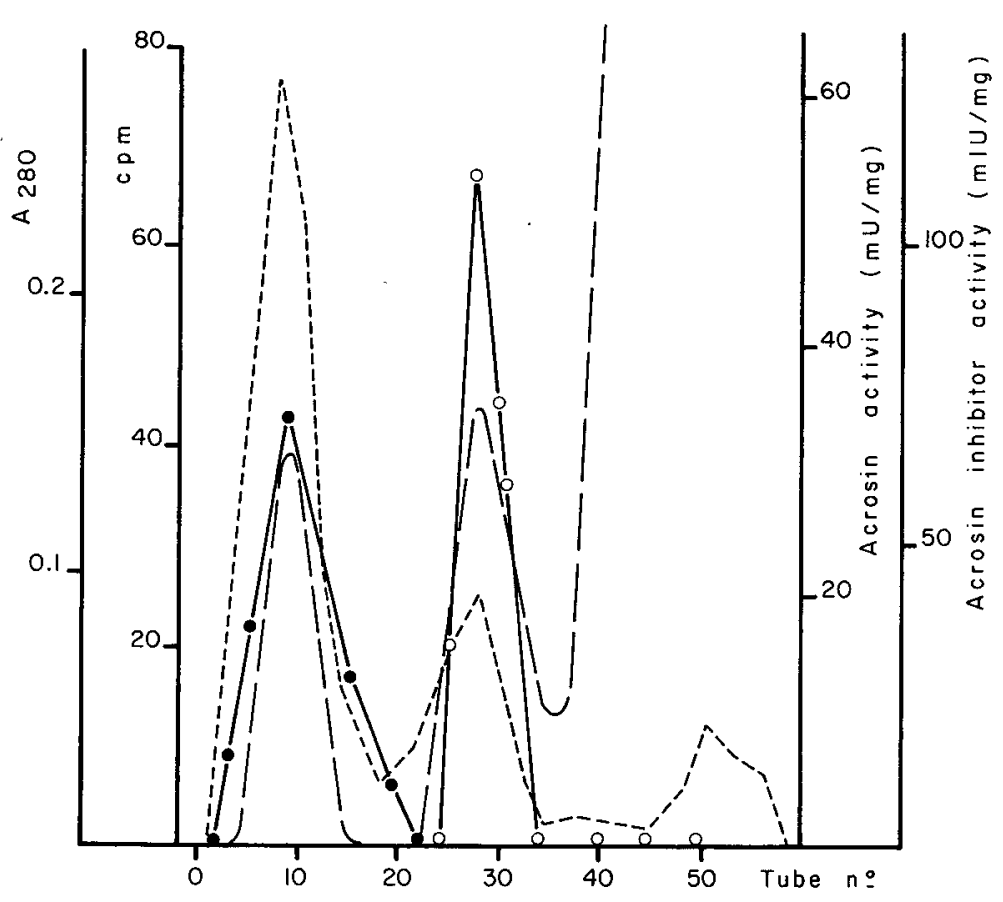

FIG. 6. - Hydrophobic affinity chromatography on Spheron P-300 of pooled proacrosin-rich fractions after gel filtration of acidic extracts of ${ }^{14} \mathrm{C}$-g/ucosamine labelled rabbit spermatozoa. - - Absorbance at $280 \mathrm{~nm}$; -..- Radioactivity (minus background); $0-0$ Acrosin activity after autoactivation; - Acrosin inhibition. Conditions : see Material and Methods.

\section{Discussion.}

Several stage-specific proteins are synthesized in mouse spermatocytes and spermatids at the time when protein synthesis rate decreases in the differentiating gamete (Kramer and Erickson, 1982). In pachytene spermatocytes and round spermatids of the same species more than 16 different glycoproteins are fucosylated within the molecular weight range of 20000 to 100000 , as shown by $\left({ }^{3} \mathrm{H}\right)$-fucose incorporation in vitro (Grootegoed et al., 1982). Since $\left({ }^{3} \mathrm{H}\right)$-fucose acrosome label is retained in ejaculated spermatozoa (Kopečný, 1976), it is supposed that at least some of the labelled glycoproteins take part in the formation of the mature acrosome, as rather complex cytological and cytochemical research has shown (reviewed in Tang et al., 1982).

Labelled sugars appear to be relatively more specific precursors of enzymatically active material of acrosomes than amino acids : after similar $\left({ }^{3} \mathrm{H}\right)$ fucose labelling in rabbit (Kopečný et al., 1980) and boar (Kopečný, Sedlaková and Čechová, unpublished results) a proteolytic activity is correlated with radioactivity in fractions of sperm extracts, but this correlation does not occur if 
labelled amino acids, like tryptophane or glycine, are used (Kopečný, Sedlaková and Čechová, unpublished).

Our present fine-structure autoradiographic detection of newly fucosylated proteins, shortly ( 3 days) after their formation in spermatids, shows that their distribution is already very similar to that in mature spermatozoa analyzed 3 weeks after labelled precursor injection (Kopečný and Fléchon, 1981). It may be concluded that the evident prevailing part of newly formed glycoproteins in spermatids is specifically concentrated very soon in the acrosome. The broad spectrum of labelling of all round stages testifies that glycoprotein was continuously added to the material of the forming acrosome. Acrosin was first detected immunohistochemically in early round spermatids (Phi-Van et al., 1983), and an increase in total acrosin was reported in late spermatids in comparison to early spermatids (Mansouri et al., 1983).

As explained in the introduction, we chose proacrosin as a test for determining the nature of labelled acrosomal glycoproteins. In the first experiment, we labelled spermatozoa with $\left({ }^{14} \mathrm{C}\right)$-fucose. The results obtained (fig. 5) show that proacrosin was most probably labelled.

As it has been reported that the sugar component of the rabbit proacrosin molecule contains more glucosamine than fucose (Mukerji and Meizel, 1979), the proacrosin isolation procedure was repeated (second experiment) with $\left({ }^{14} \mathrm{C}\right.$ )glucosamine-labelled spermatozoa. After isolation by two-step column chromatography, highly purified radioactive proacrosin was obtained. Without doubt the proacrosin was labelled with ${ }^{14} \mathrm{C}$-glucosamine. So our autoradiographic and biochemical studies suggest that proacrosin is already synthesized in spermatids, as described by Mansouri et al., (1983).

Another finding of the present study is that at least $2 \%$ of the radioactivity, introduced by $\left({ }^{14} \mathrm{C}\right)$-glucosamine and recovered in the epididymal sperm, is located in the proacrosin molecule. Most of the luminal radioactivity, as shown by autoradiography (Kopečný and Fléchon, 1981), is located solely in the acrosome, the only exception being the cytoplasmic droplet. In fact, it is supposed that the yield of radioactive proacrosin may be actually higher since Schill et al. (1982) reported that different physiochemical treatments, as opposed to acid extraction alone, increased total acrosin activity in sperm acid extracts by $50-200 \%$. Furthermore, proacrosin can be adsorbed on disrupted sperm cells (Harrison et al., 1982), thus decreasing the radioactivity of the extracts used for proacrosin isolation.

Even if a higher rate of incorporation into proacrosin actually occurred, it would not be enough to equate our ultrastructural localization of labelled glycoproteins with that of this enzyme. However, the striking similarity between label and acrosin distributions may be considered from another point of view, if our present finding of the labelling of intraacrosomal glycoprotein acrosin inhibitors is confirmed. An intracellular acrosin inhibitor from boar spermatozoa was characterized as a glycoprotein probably forming a complex with proacrosin within the acrosome (Tschesche et al., 1982). If so, an autoradiographic approach might permit the detection of labelled proacrosin/acrosin inhibitor complexes which, in turn, behave similarly to their cytochemically detectable component, 
acrosin. Also, in the guinea-pig, acrosin and acrosin inhibitor may be associated in the acrosome and released together upon acrosome reaction (Goodpasture et al., 1981).

Finally, we know that acrosomal contents are lost in two steps after acrosome reaction: readily soluble substances like hyaluronidase may diffuse instantaneously, while most of the acrosomal matrix is dispersed only when proacrosin is activated (Shams-Borhan and Harrison, 1981 ; Perreault et al., 1982 ; Harrison et al., 1982). This may ultimately explain why most glycoproteins - including (pro)-acrosin whose distribution seems homogeneous in the anterior segment (Huneau et al., 1983) - have the same location in intact acrosomes and are solubilized according to the same pattern after acrosome reaction.

Reçu en septembre 1983. Accepté en mars 1984.

Résumé. Etudes sur le marquage de l'acrosome des spermatozoïdes de Mammifères par des sucres radioactifs.

La localisation de la synthèse et du stockage de glycoprotéines pendant la formation de l'acrosome chez le cobaye a été étudiée par autoradiographie en microscopie électronique après incorporation de $\left({ }^{3} \mathrm{H}\right)$-fucose. Trois jours après I'injection intratesticulaire du précurseur, le marquage dans les spermatides est concentré dans la matrice des acrosomes en développement; il apparaît que la plus grande partie des glycoprotéines fucolysées dans les spermatides sont stockées dans l'acrosome.

La contribution relative de l'acrosine au marquage des glycoprotéines a été évaluée par voie biochimique. La recherche de l'activité acrosine a été effectuée dans des spermatozoïdes de la queue de l'épididyme de lapins obtenus 21 jours après injection intratesticulaire de $\left({ }^{14} \mathrm{C}\right)$-fucose ou $\left({ }^{14} \mathrm{C}\right)$-glucosamine. Après extraction acide et filtration sur gel, une incorporation a été obtenue dans les fractions proacrosine de tous les échantillons étudiés; la radioactivité dans la proacrosine purifiée représente au moins $2 \%$ de la radioactivité totale du matériel. L'autre pic majeur de radioactivité après incorporation de $\left({ }^{14} \mathrm{C}\right)$-glucosamine pourraît correspondre à l'inhibiteur d'acrosine intraacrosomique.

Les complexes (pro)-acrosine (inhibiteur $d$ 'acrosine) semblent donc représenter une part notable des glycoprotéines acrosomiques marquées par des sucres radioactifs; la distribution des complexes pourrait correspondre au moins partiellement à celle de leur composant cytochimiquement détectable, l'acrosine. La superposition de la localisation de l'acrosine et des autres glycoprotéines acrosomiques au cours de la réaction acrosomique peut être expliquée par le fait que la dispersion de la grande masse du contenu acrosomique suit I'activation de la proacrosine.

\section{References}

AMANN R. P., KOEFOED-JOHNSEN H. H., LÉVI H., 1965. Excretion pattern of labelled spermatozoa and the timing of spermatozoa formation and epididymal transit in rabbits injected with thymidine $-{ }^{3} \mathrm{H}$. J. Reprod. Fert., 10, 169-183.

ANDERSON R. A., OSWALD C., ZANEVELD L. J. D., 1981. Inhibition of human acrosin by monosaccharides and related compounds : structure-activity relationship. J. med. Chem., 24, 1288-1291.

COURTENS J. L., 1979. Modifications in the plasma membrane of elongated ram spermatids: a cytochemical study. Ann. Biol. anim. Bioch. Biophys., 19, 989-997. 
GADDUM P., BLANDAU R. J., 1970. Proteolytic reaction of mammalian spermatozoa on gelatin membranes. Science, N. Y., 170, 749-751.

GOODPASTURE J. C., REDDY J. M., ZANEVELD L. J. D., 1981. Acrosin, proacrosin, and acrosin inhibitor of guinea-pig spermatozoa capacitated and acrosome-reacted in vitro. Biol. Reprod., 25, 44-55.

GREEN D. P. L., HOCKADAY A. R., 1978. The histochemical localization of acrosin in guinea-pig sperm after the acrosome reaction. J. Cell Sci, 32, 177-184.

GROOTEGOED J. A., KRUGER-SEWNARAIN B. C., JUTTE N. H. P. M., ROMMERTS F. F. G., VAN DER MOLEN H. J., 1982. Fucosylation of glycoproteins in rat spermatocytes and spermatids. Gamete Res., 5, 303-315.

HARRISON R. A. P., FLECHON J.-E., BROWN C. R., 1982. The location of acrosin and proacrosin in ram spermatozoa. J. Reprod. Fert., 66, 349-358.

HUNEAU D., HARRISON R. A. P., FLECHON J.-E., 1983. Ultrastructural localization of proacrosin and acrosin during the acrosome reaction in ram spermatozoa. 4th Int. Symp. Spermatology, Seillac. In : J. ANDRE. The sperm cell. Martinus Nijhof Publ., The Hague, 286-289.

KOPEČNÝY V., 1976. Labelling of acrosomes in mouse spermatozoa by L-(I- $\left.{ }^{3} \mathrm{H}\right)$ fucose. J. Reprod. Fert., 47, 403-405.

KOPEČNÝ V., FLÉCHON J.-E., 1981. Fate of acrosomal glycoproteins during the acrosomal reaction and fertilization : a light and electron microscope autoradiographic study. Biol. Reprod., 24, 201-216.

KOPEČNYY V., SEDLÁKOVÁ E., ČECHOVÁ D., PIVKO J., STANĚK R., 1980. First attempt to characterize ${ }^{3} \mathrm{H}$-fucose acrosomal label in spermatozoa. Histochemistry, 68, 67-74.

KRAMER J. M., ERICKSON R. P., 1982. Analysis of stage-specific protein synthesis during spermatogenesis of the mouse by two-dimensional gel electrophoresis. J. Reprod. Fert., 64, 139-144.

MANSOURI A., PHI-VAN L., GEITHE M. P., ENGEL W., 1983. Proacrosin/acrosin activity during spermiohistogenesis in the bull. Differentiation, 24, 149-152.

MEIZEL S., MUKERJI S. K., 1975. Proacrosin from rabbit epididymal spermatozoa : partial purification and initial biochemical characterization. Biol. Reprod., 13, 83-93.

MUKERJI S. K., MEIZEL S., 1979. Rabbit testis proacrosin. J. biol. Chem., 254, $11721-11728$.

PERREAULT S. D., ZIRKIN B. R., ROGERS J., 1982. Effect of trypsin inhibitors on acrosome reaction of guinea-pig spermatozoa. Biol. Reprod., 26, 343-351.

PHI-VAN L., MÜLLER-ESTERL W., FLÖRKE S., SCHMID M., ENGEL W., 1983. Proacrosin and the differentiation of the spermatozoa. Biol. Reprod., 29, 479-486.

SAKAI Y., YASUDA K., 1981. Localization of acrosomal proteinase after vesiculation of the acrosome. Develop., Growth Differ., 23, 487-494.

SCHILL W. B., FEIFEL M., FRITZ H., 1982. Acid extraction of acrosin from human spermatozoa pretreated by different physicochemical methods. Arch. Dermatol. Res., 273, 273-285.

SHAMS-BORHAN G., HARRISON R. A. P., 1981. Production, characterization, and use of ionophore-induced, calcium-dependent acrosome reaction in ram spermatozoa. Gamete Res., 4. 407-432.

TANG $X$. M., LALLI M. F., CLERMONT Y., 1982. A cytochemical study of the golgi apparatus of the spermatid during spermiogenesis in the rat. Am. J. Anat., 163, 283-294.

TSCHESCHE H., WITTIG B., DECKER G., MÜLLER-ESTERL W., FRITZ H., 1982. A new acrosin inhibitor from boar spermatozoa. Eur. J. Biochem., 126, 99-104.

ŽELEZNÁ B., ČECHOVÁ D., 1982. Boar acrosin. Isolation of two active forms from boar ejaculated sperm. Hoppe-Seyler's Z. Physiol. Chem., 363, 757-766. 